\title{
Impact of Contemporary Pension Reforms on Households' Welfare
}

Submitted 12/09/19, $1^{\text {st }}$ revision 02/10/19, $2^{\text {nd }}$ revision 30/10/19, accepted 23/11/19

\author{
Abstract: \\ Nivorozhkina L.I., ${ }^{1}$ Abazieva K.G., ${ }^{2}$ Dolbina S.V. ${ }^{3}$
}

Purpose: Identification and assessment of the consequences of raising the retirement age and possible changes in the households' welfare because a part of the pre-retirement age population will remain in the labor force five years longer.

Design/Methodology/Approach: The initial data for the analysis and modeling are the data of a representative survey on the "Russian Longitudinal Monitoring Survey - HSE" project for 2017. The object of the analysis were women aged 55 and older and men of 60 years and older. Microsimulation was carried out, that is all men aged from 60 to 65 and women from 55 to 60 were conditionally transferred to the working population, and changes in their employment and incomes were estimated. Based on the econometric model, an assessment of factors that are incentives to continue working after retirement has been obtained.

Results: The presented calculations indicated the fact that despite an increase in the labor supply due to an increase of the retirement age, no employment surplus in the labor market is foreseen. Currently, the poverty level among retired households is significantly lower than the average one, and this trend will continue in the future.

Practical implications: The results are important for the adjustment of social policy for retirees.

Originality/Value: The study revealed the following new trends: 1) with the growth of the educational level, the probability of employment after the retirement age increases; 2) all other things being equal, women after retirement have a greater chance of being employed than men do; 3) for the majority of retirees employment is not traumatic.

Keywords: Retirement age, pension reform, elderly employment, households, pensions.

JEL Code: C10, D14, G02, I32.

Paper type: Research article: Pension Reforms.

\section{Acknowledgement:}

The reported study was funded by RFBR according to the research project №19-010-00009.

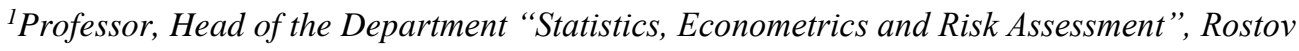
State University of Economics, Rostov-on-Don, lin45@mail.ru

${ }^{2}$ Associate Professor of the Department "Human Recourses Management and Sociology",

Rostov State University of Economics, Rostov-on-Don, abazieva_kamilla@mail.ru

${ }^{3}$ Lecturer of the Zernogradskiy College of agricultural technology, Zernograd,

Svitlanadolbina@mail.ru
} 


\section{Introduction}

The problems associated with pension reforms, which start in 2019, affect the interests of every Russian family, where there are pensioners or people approaching the retirement age. Recently, the problems of raising the retirement age have become one of the most widely discussed by the mass media and the main tone of the discussions is very negative, which often drowns out sound arguments in support of the ongoing changes (Gorlin et al., 2018).

Pension reforms in Russia started simultaneously with market reforms and their implementation coincided with different stages of the state of the country's economy, including both periods of crisis and active growth. This is both the protracted crisis of the 90s, and the intensive growth in the 2000s, interrupted in 2008, and the recovery that followed it until the fall of 2014 , broken by external anti-Russia sanctions of Western countries. The permanent nature of the reforms is due to both the process of changing the socio-economic structure, macroeconomic shocks, and the consequences of long-term demographic shifts, caused by the loss of the war years, the rising mortality rate of the predominantly male population of the country during the perestroika period, and a number of other reasons (Maleva and Sinyavskaya, 2010).

The concept of retirement insurance, adopted in 1992, suggested that during his/her working life the employee should independently save funds for retirement on special accounts. Over the past years, the mechanism for implementing the pension reform has been repeatedly adjusted, but only generations of workers born in the $60 \mathrm{~s}$ of the last century should have started to receive a pension accumulated according to these principles. With the beginning of the next crisis in 2015, pension savings were temporarily frozen, and now all old-age pensioners receive pensions according to the solidarity principle, that is, due to deductions of currently working citizens and budget allocations. The next stage of pension reforms was the decision to raise the retirement age by five years. It should be noted that the retirement age established in Russia at the end of 2018 was the lowest among the developed countries of the world. It is 4 years lower for men than the average one in European countries, and 8 years lower for women (Gorlin, 2017). To mitigate the "shock" of the transition to new retirement age limits, this process will start in 2019 and will be completed by 2028 .

Table 1. Stages of increasing the retirement age (Kurs, 2019)

\begin{tabular}{|c|c|c|c|}
\hline \multicolumn{4}{|l|}{ women } \\
\hline $\begin{array}{l}\text { Year of } \\
\text { increase }\end{array}$ & Year of birth & Age & Year of retirement \\
\hline \multirow[t]{2}{*}{2019} & 1964 (I half of the year) & $\begin{array}{l}55 \text { and a half years } \\
\text { old }\end{array}$ & 2019 (II half of the year) \\
\hline & $\begin{array}{l}1964 \text { (II half of the } \\
\text { year) }\end{array}$ & $\begin{array}{l}55 \text { and a half years } \\
\text { old }\end{array}$ & 2020 (I half of the year) \\
\hline 2020 & 1965 (I half of the year) & $\begin{array}{l}56 \text { and a half years } \\
\text { old }\end{array}$ & 2021 (II half of the year) \\
\hline
\end{tabular}




\begin{tabular}{|l|l|l|l|}
\hline & $\begin{array}{l}1965 \text { (II half of the } \\
\text { year) }\end{array}$ & $\begin{array}{l}56 \text { and a half years } \\
\text { old }\end{array}$ & 2022 (I half of the year) \\
\hline 2021 & 1966 & 58 years old & 2024 \\
\hline 2022 & 1967 & 59 years old & 2026 \\
\hline 2023 & 1968 & 60 years old & 2028 \\
\hline men & \multicolumn{3}{|l|}{} \\
\hline $\begin{array}{l}\text { Year of } \\
\text { increase }\end{array}$ & Year of birth & Age & Year of retirement \\
\hline 2019 & 1959 (I half of the year) & $\begin{array}{l}60 \text { and a half years } \\
\text { old }\end{array}$ & 2019 (II half of the year) \\
\hline & $\begin{array}{l}1959 \text { (II half of the } \\
\text { year) }\end{array}$ & $\begin{array}{l}\text { ond a half years } \\
\text { old }\end{array}$ & 2020 (I half of the year) \\
\hline 2020 & $\begin{array}{l}1960 \text { (I half of the year) } \\
61 \text { and a half years } \\
\text { old }\end{array}$ & 2021 (II half of the year) \\
\hline & $\begin{array}{l}1960 \text { (II half of the } \\
\text { year) }\end{array}$ & $\begin{array}{l}61 \text { and a half years } \\
\text { old }\end{array}$ & 2022 (I half of the year) \\
\hline 2021 & 1961 & 63 years old & 2024 \\
\hline 2022 & 1962 & 64 years old & 2026 \\
\hline 2023 & 1963 & 65 years old & 2028 \\
\hline
\end{tabular}

Significant changes in the Russian labor market will be one of the serious consequences of the new pension reform. The raise of the retirement age will inevitably affect the balance of labor demand and supply, reserve wages, the age range of persons registered by the Employment Service as unemployed will expand. In this regard, the analysis of possible changes in the economic behavior of the people aged from 55 to 60 for women and from 60 to 65 for men, that is, of those who will be the able-bodied population by 2028 is of a significant scientific and practical interest.

According to the official statistics, today these are pensioners belonging to the disabled population, but many of them continue to work, receiving both pensions and wages, while others have stopped their working activity and the main source of their income is pension benefits. In a few years, due to the new retirement age limits, the picture will change significantly: this group of pensioners will move into the category of working-age population and those who can leave work today will continue to work. What replenishment may the labor market be waiting for? What is the difference between the characteristics of "young" pensioners and older age retirement groups? How do the characteristics of working and non-working pensioners differ? How will the well-being of present-day retirees and the near future labor force change? Partly the answer to these questions may be given by the analysis of the socio-demographic group of pensioners who will become the working-age group in the coming years.

\section{Data Sources}

The data source for analyzing the possible consequences of raising the retirement age is the Russian Monitoring of the Economic Situation and Public Health of the National 
Research University Higher School of Economics ((The Russian Long Monitoring Survey (RLMS-HSE)), conducted since 1992 through a nationwide Russian sample and intended to study various aspects of the health and economic welfare of households and individuals in the Russian Federation. The RLMS data represent the population of Russia and the characteristics obtained through the sample are close to those published by official statistics.

Each year surveys are presented in two files: the one with the results of a household survey, the other one - of individuals. Indicators characterizing households reflect their socio-demographic structure, joint income and expenses are detailed. Individuals are represented by a wide range of characteristics, including educational, professional level, state of employment, sources and levels of individual incomes, health, and many others. The monitoring program includes several indicators that are not used by the state and departmental statistics, but which are essential for analysts.

We used data from the latest survey of 2017. In 2017, 12,441 people were interviewed, among whom $30.25 \%$ were people of the retirement age. The object of the analysis was the old-age pensioners, that is, women aged 55 and older and men aged 60 and older. The characteristics of the household in which they live are added to the individual characteristics of pensioners interviewed. To simplify the analysis, we did not consider the process of gradual transition to new retirement age limits but modeled a conditional situation in which all men aged 60 to 65 and women 55 to 60 become members of the working-age population.

\section{Descriptive Statistics}

For further analysis pensioners was grouped into three age groups: the first group included women under the age of 60 , men under the age of 65; the second group women aged 60, men aged 65 to 70; the third group consisted of people of 70 years old and older (Table 2).

Table 2. Socio-demographic characteristics of pensioners of various age groups (\%)

\begin{tabular}{|l|l|l|l|}
\hline & $\begin{array}{l}\text { Pensioners under } \\
\text { the age of 60 for } \\
\text { women, 65 for } \\
\text { men }\end{array}$ & $\begin{array}{l}\text { Pensioners of 60 years old and } \\
\text { above to 70 for women and from } \\
65 \text { years old and above to 70 for } \\
\text { men }\end{array}$ & $\begin{array}{l}\text { Pensioners } \\
\text { older than 70 } \\
\text { years old }\end{array}$ \\
\hline & 1 group & 2 group & 3 group \\
\hline $\begin{array}{l}\text { Share of } \\
\text { pensioners in the } \\
\text { group }\end{array}$ & 29,64 & 36,03 & 34,32 \\
\hline Men & 38,77 & 20,85 & 27,54 \\
\hline Family status & & & 34,46 \\
\hline Singles & 12,60 & 21,74 & 26,10 \\
\hline Spouses & 38,23 & 35,75 & 39,44 \\
\hline $\begin{array}{l}\text { Other type of } \\
\text { cohabitation }\end{array}$ & 49,18 & 42,52 & \\
\hline
\end{tabular}




\begin{tabular}{|l|l|l|l|}
\hline Education & & & \\
\hline Below average & 20,04 & 21,19 & 39,94 \\
\hline $\begin{array}{l}\text { General } \\
\text { secondary } \\
\text { education }\end{array}$ & 29,13 & 24,20 & 12,98 \\
\hline $\begin{array}{l}\text { Professional } \\
\text { secondary }\end{array}$ & 27,60 & 31,85 & 21,70 \\
\hline Higher & 21,25 & 19,96 & 23,14 \\
\hline $\begin{array}{l}\text { Place of } \\
\text { residence }\end{array}$ & & & \\
\hline Large city & 37,46 & 39,58 & 47,73 \\
\hline Town & 26,40 & 27,68 & 21,77 \\
\hline $\begin{array}{l}\text { Urban-type } \\
\text { settlement }\end{array}$ & 6,79 & 7,52 & 6,92 \\
\hline Village & 29,35 & 25,22 & 23,58 \\
\hline $\begin{array}{l}\text { Health } \\
\text { assessment }\end{array}$ & & & 6,06 \\
\hline Healthy & 16,32 & 10,25 & 47,66 \\
\hline Both yes and no & 69,11 & 65,10 & 46,29 \\
\hline Not healthy & 14,57 & 24,74 & 4,90 \\
\hline Employed & 49,62 & 22,42 & \\
\hline
\end{tabular}

Among the 12,441 selected individuals, $47.04 \%$ were employed at the time of the survey. This subset included $7.34 \%$ from the first group pensioners, $11.76 \%$ from the second, $11.15 \%$ from the third one. Among working pensioners, $85.45 \%$ were younger of the retirement age, $7.74 \%$ of employees were in the first group, $5.60 \%$ in the second, $1.16 \%$ in the third. In terms of the number of pensioners, the first group was $24.26 \%$. The share of non-working pensioners among them was $15.79 \%$ (Table 3 ). Thus, in conditions of a gradual increase of the retirement age, this group of nonworking pensioners when become the labor force will be of a small additional burden on the labor market and most likely there will be no massive problems with the creation of new jobs opportunities.

Table 3. The relationship between age and status in employment sphere

\begin{tabular}{|l|l|l|l|}
\hline \multirow{2}{*}{ Age group } & \multicolumn{2}{|l|}{ Employment state } & Total \\
\cline { 2 - 4 } Employable & 3675 & 5003 & 8678 \\
& 42,35 & 57,65 & 100,00 \\
& 55,77 & 85,49 & 69,75 \\
\hline At the age under 60 years old for & 460 & 453 & 913 \\
women, 65 years old for men & 50,38 & 49,52 & 100,00 \\
\hline At the age of 60 years old and & 6,98 & 7,74 & 7,34 \\
above to 70 for women and from & 1135 & 328 & 1463 \\
65 years old and above to 70 for & 77,58 & 22,42 & 100,00 \\
men & 17,23 & 5,60 & 11,76 \\
\hline
\end{tabular}




\begin{tabular}{|l|l|l|l|}
\hline Above 70 years old & 1319 & 68 & 1387 \\
& 95,10 & 4,90 & 100,00 \\
& 20,02 & 1,16 & 11,15 \\
\hline Total & 6589 & 5862 & 12441 \\
& 52,96 & 47,04 & 100,00 \\
& 100,00 & 100,00 & 100,00 \\
\hline
\end{tabular}

A characteristic feature of the demographic situation in Russia is that the life expectancy of women is ten years longer than that of men. Accordingly, in the older age group there is a significant predominance of female pensioners not only in Russia but in other countries as well (Vishnevskiy, 2016; Rupeika-Apoga et al., 2019; Cristea and Thalassinos, 2016). The older are the pensioners, the greater the number of people with a low level of education. The generation where a significant number of jobs occupied by pensioners presupposed mostly low qualifications becomes a part of the history. It is expected that in the process of aging the number of single pensioners increases, there are fewer married couples, but the tendency for pensioners to live in numerous households remains predominant.

Self-assessments of health are extremely low among pensioners and decrease quite naturally over the years: for example, $16.3 \%$ of "young" pensioners consider themselves healthy and, accordingly, only $6.1 \%$ of "elderly" do the same. One of the most pressing arguments against raising the retirement age is the statement about the poor health of the elder generation (Aganbegyan, 2015). However, it is believed that socialization is of great importance in old age, especially for single people. It may be proved by the fact that exacerbation of chronic diseases, rapid aging occurs after retirement and stopping working activity (Behncke, 2009; Gallo, 2013; Henkensetal, 2008; Slingerlandetal, 2007).

The presented groups clearly indicate that the first group of pensioners differs significantly in its characteristics from the second and third age groups and, above all, in its high level of employment. At the time of the survey, $22.6 \%$ of the total number of pensioners continued to work, but $49.6 \%$ worked in the first group, $23.9 \%$ in the second and only $5.9 \%$ in the third. By the time when the age reaches the limits defined by the current reform as a retirement one, the share of workers is reduced more than twice and drops sharply after seventy years.

Motives for continuing professional activity after retirement are described in both domestic (Tecernina and Techernin, 2002; Lyashok and Roshchin, 2017) and foreign sources (Gerber and Radl, 2014; Gustafsson et al., 2015; Levin, 2015; Cristea and Thalassinos, 2016). The main ones are:

- individual characteristics of the employee (health, age, education);

- segmentation of the labor market: primary, secondary, migration, employer pressure, unemployment rate;

- the share of pensioners in the total population, the system of social support, the fact 
that all pensioners receive pensions, differentiation of pension benefits;

- the role of family and cultural traditions, investments in children, assistance in caring for grandchildren;

- experience of the past and expectation of the future between the age cohorts, burdened by low faith in the pension system;

- life expectancy after retirement.

In accordance with standard economic theory, the choice of an employee between leisure and work is that a high pension, as well as income from capital, will lead to an individual preferring leisure to work. However, capital gains are not widespread among Russian pensioners, and the size of pensions among those who receive an oldage labor pension is not very differentiated.

\section{Modeling Factors of Working Activity after Retirement}

A comprehensive assessment of the factors influencing the decision of the pensioner to continue working activity was carried out using a logistic regression model in which the dependent variable takes a value equal to one if the pensioner is working and equal to zero in the opposite case. The characteristics presented in Table 4 are used as regressors. To estimate the influence of the pension amount on the decision to continue the working activity variables indicating the quartile number to which the pension belongs were designed. All the model variables are of binary type.

Table 4. The results of the evaluation of the logistic model

Dependent variable: the pensioner is working $=1$, not working $=0$

\begin{tabular}{|l|l|l|}
\hline Variables & $\begin{array}{l}\text { Odds } \\
\text { ratios }\end{array}$ & $\begin{array}{l}\text { Standard } \\
\text { errors }\end{array}$ \\
\hline Age groups (base: second age group) & - & - \\
\hline The first age group & $3,448^{* * * *}$ & 0,348 \\
\hline The third age group & $0,235^{* * *}$ & 0,035 \\
\hline Education (base: incomplete secondary) & - & - \\
\hline General secondary education & 1,003 & 0,137 \\
\hline Professional secondary & $1,633^{* * *}$ & 0,210 \\
\hline Higher & $2,566^{* * *}$ & 0,352 \\
\hline $\begin{array}{l}\text { Type of accommodation (base: urban-type settlement, } \\
\text { village) }\end{array}$ & - & - \\
\hline Regional city & $1,449^{* * *}$ & 0,165 \\
\hline City & $1,441^{* * *}$ & 0,173 \\
\hline Type of household (base: another type of family) & - & - \\
\hline Single & 1,005 & 0,123 \\
\hline Spouses & 0,919 & 0,095 \\
\hline Health self-esteem (base: bad and very bad) & - & - \\
\hline Good and very good & $4,480^{* * *}$ & 0,751 \\
\hline Both yes and no & $2,520^{* * *}$ & 0,323 \\
\hline Gender (base: female) & $0,763^{* *}$ & 0,083 \\
\hline Pension quartile (base: 4 quartile) & - & - \\
\hline
\end{tabular}




\begin{tabular}{|l|l|l|}
\hline 1 quartile & $1,624^{* * *}$ & 0,261 \\
\hline 2 quartile & $1,719^{* * *}$ & 0,264 \\
\hline 3 quartile & $1,409^{* *}$ & 0,217 \\
\hline Constant & $0,049^{* * *}$ & 0,011 \\
\hline $\mathrm{R}^{2}$ & 0,217 & \\
\hline
\end{tabular}

Note: ***, **, *-the coefficient is significant at 1, 5 and 10\% level, respectively. In brackets - standard errors.

Table 4 presents the results in terms of the odds ratio, which makes their interpretation clearer. The dependent variable $\mathrm{Y}$ take a value equal to one if the pensioner is working. In turn, the independent variable $\mathrm{X}$ reflects, for example, the gender. This variable takes on a value of zero if the pensioner is female and equal to one if it is male. The chances of working for male pensioners are exp $\left(\beta \_0+\beta \_1 X\right)$, and for women - $\exp \left(\beta \_0\right)$. Then the odds ratio is expressed by the following formula:

$$
O R=\frac{\operatorname{odds}(Y=1 \mid X=1)}{\operatorname{odds}(Y=1 \mid X=0)}=\frac{\exp \left(\beta_{0}+\beta_{1} X\right)}{\exp \left(\beta_{0}\right)}=\exp \left(\beta_{1}\right)
$$

An odds ratio of one indicates that there is no difference between men and women. If these OR > 1, then men chances of working are greater than those of women. If OR < 1, then women have more the chances for working activity (Long, 1997).

In the case under consideration (Table 4), the odds ratio indicates that the chances of working for a male pensioner are $76.3 \%$ of the females' chances, which is to some extent explained by a higher life expectancy of women and their significant predominance in older age groups. Men are more likely to be engaged in those professional spheres where highly intensive physical activity prevails. Women predominantly engaged in school education, medicine, culture, etc. The relatively low wages in these sectors reduce competition from the younger part of the workforce, which leads to the predominance of women among working pensioners.

Compared to the second group of pensioners, the chances that the "young" pensioners will continue to work are more than three times higher, and the chances of the third group of pensioners are less than a quarter of the chances of the second group. The result can be explained by several reasons. First, it is better health condition, which allows many pensioners to continue their working activity. One of the explanations of the result can be the fact that a woman who often retires before her spouse "expects" him to retire as well. And, of course, the fact that many working pensioners stay at the same workplace and consider pension benefits as a certain age "bonus" to wages.

The growth of the educational level dramatically increases the chances to continue professional activity. Low education level implicitly suggests a type of employment where physical activity prevails, and age wear and tear, fatigue occurs earlier than among those who are engaged in mental work. Compared with the villagers and residents of urban-type settlements, urban pensioners more often remain in the labor 
force, which is quite understandable by the wide diversification of the urban labor market.

The family status of a pensioner, other things being equal, is not a stimulus for working activity, which indirectly indicates a weakening of the role of pensioners, especially women, in helping with household work and in looking after their grandchildren. Moreover, a working pensioner often makes a material contribution to the family income, allowing its younger members to pay more attention to the younger generation. The smaller the pension, the higher the chances that the pensioner will continue to work. Estimates of the logistic model with variables indicating which quartile the size of the monthly pension relates to clearly demonstrate this relationship (Dolbina and Tregubova, 2014).

\section{Assessing the Impact of Raising the Retirement Age on Wages, Incomes and Poverty Levels of Households}

Working activity after retirement, surely, affects household welfare. In 2017, per capita incomes in households where non-working pensioners lived made up $69.8 \%$ compared with working pensioners' households (17258 and 24735 rubles, respectively). The average pension for working pensioners was 11255 rubles, and 12110 rubles for non-working pensioners, which confirms, on the one hand, that the value of free time increases with income increase, and, on the other, it marks that the reason for working activity after retirement is often income decrease. The average salary of working pensioners was 20478 rubles, it means that it is their wages that are the basis of a higher level of well-being of working pensioners households.

In the context of the analysis, the focus of interest is on the first group of pensioners, that is, those who will continue their professional activity in the foreseeable future. To predict what will happen to this part of the population that will experience the main impact of the new pension reform, we should consider the following hypothetical situation. Suppose that working pensioners remain at their workplaces and receive the same wages, but the source of income in the form of a pension will disappear. Those who are not employed now will become employees, but the question remains: what kind of wages should they receive in this situation?

To implement this procedure, a regression salary model for a complete data set was specified, the evaluation of which, in order to eliminate bias due to zero wage, was carried out under the condition that the pensioner works and belongs to the first age group. Then, the non-working pensioners of the first group were assessed by the wage values predicted by the model, the same model was used for working pensioners with similar characteristics. As a result of the simulation, the estimated average salary of non-working pensioners was 18144 rubles, which is slightly lower than 20478 rubles of working pensioners. The share of the first age group households, whose incomes will decrease due to changes in the pension status, was $16.1 \%$. 
Today, the salary of working pensioners makes a significant contribution to the wellbeing of the family. Per capita incomes in households where there are working pensioners belonging to the first age group are higher than where pensioners do not work. And what will happen to the poverty level in connection with the raise of the retirement age? The level of income equal to $50 \%$ of the median income for the total of households, which amounted to 7557 rubles, was chosen as the poverty threshold. The overall poverty level calculated by the criterion selected was $14.0 \%$ for all households. The assessment showed that the level of poverty among households of pensioners of the first group turned out to be $7.45 \%$. In case of working pensioners in the household the poverty level is reduced to $5.74 \%$, and it increases to $9.13 \%$ if pensioners are the working ones.

And what will happen to the level of poverty if the first group of pensioners enters the working-age population? If we deduct the pension contribution from the per capita incomes of the first group pensioners and consider the imputed salary, then the overall poverty level will rise to $8.3 \%$. Among those pensioners who worked and received their pension benefits, the elimination of pensions will lead to poverty increase up to $11.54 \%$, while the imputation of salary and the elimination of pensions among nonworking pensioners leaves the poverty level almost unchanged - 5.22\%. The share of this group being not so large among the population, the problem can be solved by targeted social programs.

\section{Conclusions}

The retirement age raise impact assessments on the population that will join the working age population in the next few years, namely, women aged 55 to 60 and men aged 60 to 65, were based on data from sample surveys of the Russian monitoring economic situation and public health for 2017. The figures presented in the analysis do not fully coincide with the official statistical indicators, but considering the representativeness of the data, the error is in the area of permissible error limits and the results fully reflect the current tendencies.

One of the debatable topics when discussing pension reform is the possibility of increasing tension in the labor market by the remaining workers. The calculations presented show that there should not be a significant shortage of jobs considering the size of this group and the fact that half of the pensioners in this group are working pensioners.

The advantage of the analysis undertaken is that using the microdata allows researchers to view the problem from the perspective of the behavior of individuals, households. In the course of the study, a tendency was revealed which highlights the relationship between working activity after retirement and an increase in the educational level. A new result is that other things being equal, women after retirement have a greater chance of professional activity than men. The function of the "grandmother-pensioner" helping to raise grandchildren is becoming a thing of 
the past. An indirect confirmation of this is the lack of a relationship between the type of household and the employment of retirees.

Self-assessments of health in a selected group of pensioners confirm that for most pensioners working activity is not traumatic. The analysis proved that the prevailing strategy of retirees in the period of the first five years after retirement is to continue professional activity. Such motivating factors as active life position, the desire to maintain a decent level of household welfare and the level of education, which guarantees a high salary, are the predominant ones to stimulate working activity after retirement. The lack of a number of jobs, population aging, a low retirement age limit and the absence of employment restrictions after retirement are the main factors influencing the dynamics of transitions from an employment state at working age to an employment state at unemployable age, and only then into an unemployment state that has been more and more intense in recent years.

One of the serious reasons of the negative attitude to the raise of the retirement age is the possibility of receiving both a pension and a salary without any restrictions which was one of the powerful incentives of working activity. As the analysis shows, incomes of households with working pensioners are much higher than average ones due to pensioners' contribution to the family budget. The fact that a certain percentage of the population will lose their pension bonuses for five years at the ages of 55 and 65 and this will negatively affect their well-being causes a strong rejection of the new pension reform from the population (Skvortsova, 2016).

A hot topic in public come to the mass consciousness at the crisis of the 1990s, and from time to time it reappears both in scientific publications and in the press. Indeed, on average, the level of pensioner household welfare is not high, but it is not lower than the average level in the country. Moreover, the possibility of professional activity after retirement and retaining both pension payments and wages often brings pensioners to a group of people with a high level of well-being. Currently, the poverty level among pensioner households is significantly lower than the average poverty level and the presented results confirm this fact.

In the course of the implementation of pension reform, adequate mechanisms are to be created to support both those remaining in the workforce and generations leaving the labor force, a comprehensive analysis is needed in which the dynamics of the structure and number of pensioners, the size of pension payments, their ratio to the minimum subsistence level, wages, etc., should be considered in the context of the rules for the pension system financing, as well as the macroeconomic situation in the country at different periods of time. An integral part of the general analysis is the study of the behavior of pensioner households, considering the interests of all members of this basic unit of the society, since the state's influence is mediated by the pensioner's immediate environment. 


\section{References:}

Aganbegyan, A. 2015. About Healthy Life Expectancy and Pension Age. ECO, 9, 144-157. Behncke, S. 2009. How Does Retirement Affect Health? IZA Discussion Paper, 4253.

Cristea, M., Thalassinos, I.E. 2016. Private Pension Plans: An Important Component of the Financial Market. International Journal of Economics and Business Administration, 4(1), 110-115.

Dolbina, S.V., Tregubova, A.A. 2014. Statistical assessment of the impact of socio-economic and demographic characteristics on the pension strategies of Russians. Accounting and Statistics, 3(35), Rostov-on-Don.

Gallo, W. 2013. The Association of Retirement with Physical and Behavioral Health. The Oxford Handbook of Retirement. NY, Oxford University Press, 325-338.

Gerber, T.P., Radl, J. 2014. Pushed, Pulled, or Blocked? The Elderly and the Labor Market in Post-Soviet Russia. Social Science Research, 45, 152-169.

Gorlin, Yu. 2017. On the Economic Incentives for the Delayed Retirement. Economic Policy, 1(12), 84-113.

Gorlin, Yu., Lyashok, V., Maleva, T. 2018. Pension Age Increase: Effects and Possible Risks Economic Policy, 1(23), 148-179.

Gustafsson, B., Li, S., Nivnorozhkina, L. Wan, H. 2015. Yuan and Roubles: Comparing Wage Determination in Urban China and Russia at the Beginning of the New Millennium. China Economic Review, 35, 248-265.

Henkens, K., Solinge, H., Gallo, W. 2008. Effects of Retirement Voluntariness on Changes in Smoking, Drinking and Physical Activity Among Dutch Older Workers. European Journal of Public Health, 6(18), 644-649.

Kurs. 2019. Pension Reform. Available online: https://kurs.com.ru/novost/44546pensionnaja-reforma-tablica-vihoda-na-pensiju-s-2019-goda/.

Levin, V. 2015. Promoting Active Aging in Russia: Working Longer and More Productive. Washington D.C. The World Bank.

Long, S. 1997. Regression Models for Categorical and Limited Depended Variables. Thousand Oaks, CA, Sage Publications.

Lyashok, V., Roshchin, S. 2017. Young and Older Workers in the Russian Labor Market: Are They Competitors? Journal of the New Economic Association, 1, 117-140.

Maleva, T., Sinyavskaya, O. 2010. Age Increase: Pro et Contra. Journal of the New Economic Association, 8, 17-139.

Rupeika-Apoga, R., Romanova, I., Bule, L., Thalassinos, E.Y. 2019. The Impact of Population Ageing and Social Stratification: The Case of Latvia. International Journal of Economics and Business Administration, 7(1), 49-63.

Skvortsova, V. 2016. Retirement Age Postponement in the Conditions of Modern Russia: Possible Benefits and Risks. Russian Journal of Labor Economics, 2, 183-198.

Slingerland, A., Lenthe, V., Jukema, F., Kamphuis, C., Looman, C., Giskes, K., Huisman, M., Narayan, V., Mackenbach, J., Brug, J. 2007. Aging, Retirement, and Changes in Physical Activity: Prospective Cohort Findings from the GLOBE Study. American Journal of Epidemiology, 15(165), 356-1363.

Tecernina, N.V., Techernin, E.A. 2002. Older People in Russia's Transitional Society: Multiple Deprivation and Coping Responses. Ageing and Society, 22, 543-562.

Vishnevskiy, A.G. 2016. Demographic Modernization of Russia 1900-2000. Moscow, Novoe izdatel'stvo. 